$p$-ISSN 1693-9484, $e$-ISSN : 2621-8313

Majalah Ilmiah Bahari Jogja (MIBJ)

Vol. 16 No. 2, Juli 2018 (168-181)

(C) 2018 Akademi Maritim Yogyakarta

\title{
Aplikasi Sistem Informasi Logistik dan perannya dalam menunjang peningkatan kinerja ekspor \\ (sebuah pemikiran untuk PT Perkebunan Nusantara X Indonesia - Kab.Jember)
}

Sofian Winarto ${ }^{1}$, Nuryanto ${ }^{2 *}$

${ }^{1}$ Alumni Prodi KPN STIMART"AMNI" Semarang

${ }^{2}$ Prodi KPN SIMART"AMNI" Jl. Soekarno - Hatta No. 180 Semarang

* Corresponding Author. E-mail: nurinang@yahoo.co.id. Hp: +628122515006

\begin{abstract}
Abstrak
Tulisan ini disusun berdasarkan hasil Praktek Darat Taruna STIMART"AMNI" pada PT Perkebunan X Kabupaten Jember, merupakan sebuah pemikiran untuk PT Perkebunan X Jember, untuk mengguna kan aplikasi Sistim Informasi Logistik (SIL) guna menunjang peningkatan kinerja ekspornya, mengingat PTP X Jember, sangat potensial ekspor tembakau terutama ke negara Amerika dan Eropa. Standar dan kualitas produk ekspor memerlukan pengelolaan rantai pasokan yang efektif. Komoditas pertanian seperti tembakau mensyaratkan kualitas tembakau yang baik dan pasokan tembakau yang mencukupi serta kontinu. Hal ini dapat dicapai dengan memanfaat kan Sistem Informasi Logistik. Pemikiran ini menitik beratkan pada dua hal yaitu : Aplikasi SIL dan peningkatan Kinerja Ekspor, berdasarkan teori - teori, empiris dan penelitian-penelitian yang mendahuluinya. Hasilnya diharapkan dengan menggunakan aplikasi SIL, kinerja ekspor tembakau yang dilakukan oleh PT perkebunan X Kabupaten Jember semakin meningkat.
\end{abstract}

Kata Kunci : Sistem Informasi Logistik, Peningkatan Kinerja Ekspor.

\begin{abstract}
This paper was compiled based on the results of the Taruna STIMART "AMNI" Ground Practice at PT Perkebunan X Kabupaten Jember, a thought for PT Perkebunan X Jember, to use the Logistics Information System (SIL) application to support its export performance improvement, given PTP X Jember, very potential export of tobacco, especially to American and European countries. Standards and quality of export products require effective supply chain management. Agricultural commodities such as tobacco require good tobacco quality and sufficient and continuous tobacco supply. This can be achieved by utilizing the Logistics Information System. This thinking focuses on two things, namely: SIL application and improvement in export performance, based on theories, empirical and research that preceded it. The results are expected by using SIL applications, tobacco export performance carried out by PT X Regency Jember plantation is increasing.
\end{abstract}

Keywords: Logistics Information System, Improved Export Performance. 


\section{PENDAHULUAN}

Menurut data di BKKBN sampai bulan Juli 2017 jumlah penduduk Indonesia lebih dari 262 juta hal ini berdasarkan perhitungan laju pertumbuhan penduduk Indonesia saat ini masih di angka 1,49 persen, sehingga dalam satu tahun penduduk Indonesia bertambah sekitar 4 juta jiwa. Hal ini memberikan implikasi terhadap tingkat kebutuhan akan sandang, pangan dan papan yang cukup besar. Kebijakan pemerintah untuk melaksanakan kegiatan perdagangan internasional adalah untuk memenuhi semua kebutuhan masyarakat yang tidak bisa terpenuhi oleh produk dalam negeri. Menurut Hamdani (2004:1) perdagangan Internasional adalah kegiatan yang berlangsung melintasi negara dan benua yang sudah tentu mempunyai peraturan-peraturan hukum dan budaya yang berbeda maupun cara berdagangnya. Sedangkan menurut Hamdani (2004:2), Ekspor adalah menjual barang keluar peredaran Republik Indonesia dan barang yang di jual tersebut dilaporkan kepada Direktorat Jenderal Bea dan Cukai Kementrian Keuangan.

Dalam rangka meningkatkan ekspor, pemerintah terus berupaya membangun kualitas produk dalam negeri agar dapat bersaing dengan produk luar. Perdagangan luar negeri, khususnya ekspor, memerlukan manajemen rantai pasokan dan sistem logistik ekspor yang dapat diandalkan. Selain standar dan kualitas produk yang ketat, ekspor mensyaratkan pengiriman produk secara tepat waktu dengan kondisi produk yang sangat baik. Dr. Zaroni, CISCP., CFMP "meningkatkan ekspor Indonesia", (Head of Consulting Division Supply Chain Indonesia http://supplychainindonesia.com/new/- diunduh tanggal 30 Juni 2018)

Disamping itu, standar dan kualitas produk ekspor juga memerlukan pengelolaan rantai pasokan yang efektif. Produk-produk olahan dari komoditas pertanian seperti tembakau mensyaratkan kualitas tembakau yang baik dan pasokan tembakau yang mencukupi serta kontinu. Tembakau sendiri tumbuh subur di beberapa daerah di Indonesia, termasuk salah satunya di Kabupaten Jember yang menjadikan tembakau sebagai icon kota Jember. Dari beberapa jenis tanaman tembakau, tembakau Besuki Na-Oogst merupakan jenis tembakau yang paling banyak ditemukan di Kabupaten Jember dan Bondowoso. Tembakau Besuki Na- 
Oogst merupakan tembakau yang dijadikan sebagai bahan pokok dalam pembuatan cerutu. Berbeda halnya dengan jenis tembakau lainya, tembakau Besuki Na-Oogst memiliki tingkat kelenturan dan rasa yang lebih baik sehingga produsen rokok cerutu luar negeri menjadikan tembakau Besuki Na-Oogst produksi Jember sebagai sasaran utama untuk dijadikan bahan baku pembuatan cerutu, dengan pangsa pasar utama diekspor ke industi rokok cerutu, diantaranya :

Tabel 1: Negara tujuan ekspor tembakau

\begin{tabular}{|r|l|l|}
\hline No & Nama Industri Cerutu & Negara tujuan ekspor \\
\hline 1. & Burger Soehne Ag Burg (BSB) & Swiss \\
2. & Scandinavian Tobacco Group (STG) & Belanda \\
3. & Consolidated Cigar Corporation (CCC) & Denmark \\
4. & Villiger & Belgia \\
5. & Altadist/Tabacelara & Amerika \\
6. & Altadist/Seita & Swiss \\
7. & Swedis Match & Spanyol \\
8. & Royal Agio & Perancis \\
& & Swedia \\
& & Belanda \\
\hline
\end{tabular}

Sumber : hasil Prada Taruna STIMART"AMNI" : Sofian Winarto pada PTP X Kab.Jember bulan April 2016

Hampir setiap tahun, pihak Kebun Ajung Gayasan mengekspor sekitar 1.500 ton tembakau ke Swiss, Jerman, Belanda, Denmark, dan negara Eropa lainnya," (Sumber : Wawancara dengan Manajer Tanaman Tembakau Bawah Naungan (TBN) Kebun Ajung Gayasan PTPN X, 14 April 2016). Selanjutnya dijelaskan bahwa penanaman tembakau TBN akan dimulai pada Mei-Juni 2016, sedangkan untuk Na Oogst biasanya ditanam pada bulan Agustus-September. Penanaman tembakau cerutu yang diekspor ke sejumlah negara Eropa tersebut sudah sesuai standar Coresta, sehingga tingkat residu pesti sida sudah dikendalikan sesuai dengan standar Coresta tersebut.

Tembakau tersebut dijual ke produsen cerutu secara langsung tanpa melalui pedagang (trader). Selain pasar utama di Eropa dan Amerika Serikat, perseroan juga mulai melirik pasar di Republik Rakyat Cina yang terus berkembang seiring perubahan gaya hidup masyarakat.

Oleh karena itu, pemilihan pemasok bahan baku dan menjamin kontinuitasnya perlu menjadi perhatian para eksportir. Persediaan bahan baku untuk 
menjaga kontinuitas produksi, pemilihan lokasi, fasilitas produksi dan pergudangan serta strategi distribusi produk ekspor perlu dikelola dengan baik. Logistik berperan penting dalam ekspor. Dua hal penting pengaruh logistik terhadap kinerja ekspor adalah ketepatan pengiriman produk dan biaya logistik ekspor. Hal ini dapat ditunjang dengan adanya kecepatan penyajian Informasi dan akses data yang merupakan salah satu media pendukung suatu organisasi untuk memenangkan persaingan. Oleh karena itu, perancangan dan pengembangan suatu Sistem Informasi yang tepat dan optimal akan dapat membantu suatu perusahaan dalam meningkatkan kinerja ekspornya. Informasi dipandang sebagai sumber daya yang sangat potensial, tetapi perlu disadari faktor penunjang yang terpenting adalah informasi perusahaan dalam bentuk sistem.

\section{KAJIAN PUSTAKA}

\section{Pengertian Sistem Informasi Logistik}

Kata logistik berasal dari bahasa Yunani : logos yang berarti "rasio, kata, kulkasi, alasan, pembicaraan, orasi”. Kata logistik memiliki asal kata dari bahasa Prancis loger yaitu untuk menginapkan atau menyediakan (Herry Gunawan, 2015). Sedangkan pengertian lain dari logistik adalah kegiatan pengadaan dan penyaluran fisik produk, barang-barang yang dibutuhkan dalam proses pelaksanaan aktivitas untuk mencapai suatu tujuan, berkaitan dengan penyampaian produk sampai ke tempat tujuan (konsumen) yang membutuhkan produk tersebut (Suwarno, 2011).

Logistik dalam cetak biru Penataan dan Pengembangan Sektor Logistik Indonesia (2008) secara sederhana, dapat didefinisikan sebagai penyediaan suatu barang yang dibutuhkan yang pengadaannya dapat dilakukan langsung oleh pihak yang membutuhkan atau dilakukan oleh pihak lain. Dalam perkembangannya, persepsi tentang logistik berubah, logistik dipersepsikan bukan lagi suatu barang yang dibutuhkan tetapi proses mengadakan barang kebutuhan tersebut dipersepsikan sebagai logistik. Dalam proses pengadaan barang, berbagai kegiatan harus dilalui. Mulai dari lokasi dimana bahan baku itu dihasilkan diangkut ketempat pengolahan untuk menjadikannya bahan jadi yang selanjutnya didistribusikan kepada pelanggan yang tersebar diberbagai tempat harus dilakukan melalui secara 
efisien, tepat manfaat dalam waktu yang singkat agar harga produk dapat terjangkau oleh konsumen.

Manajemen Logistik adalah bagian dari Supply Chain Management (Manajemen Rantai Pasok) yang merencanakan, melaksanakan dan mengendalikan aliran barang secara efektif dan efisien, meliputi transportasi, penyimpanan, distribusi dan jasa layanan serta informasi terkait mulai dari tempat asal barang sampai ke tempat konsumsi untuk memenuhi kebutuhan pelanggan, Siahaya (2012) dalam Onny Fitriana,S (2015). Manajemen logistik adalah unik, karena dia merupakan aktivitas perusahaan yang tertua sekali gus termuda. Aktivitas logistik (lokasi, fasilitas, transportasi, inventarisasi, komunikasi, pengurusan dan penyimpanan) telah dilaksanakan sejak awal spesialisasi komersial. Melalui proses logistiklah, material mengalir ke komplek manufacturing yang sangat luas dari negara industri dan produk-produk didistribusikan melalui saluran-saluran distribusi untuk konsumen, sebagai dijelaskan pada Gambar 1, dibawah ini :

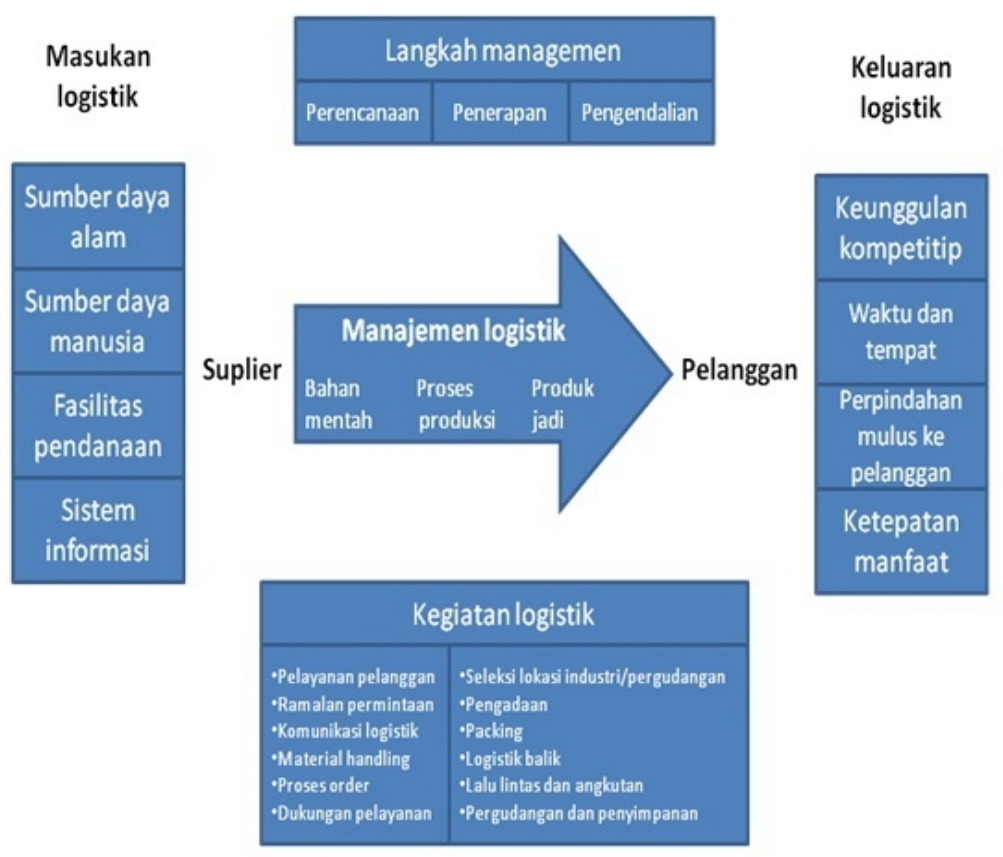

Gambar 1: Manajemen Logistik

Sumber : http://ekonomitransportasi.blogspot.com/2011/05/ peran-transportasi-multimoda-dalam.html 
Sistem informasi logistik adalah jaringan komunikasi yang lebih luas yang ada di dalam organisasi atau perusahan yang harus dibuat persiapan untuk membuat atau mengirim serta dapat menerima informasi yang disapaikan oleh organisasi atau perusahaan (Nani Imaniyati”Sistem Informasi Logistik dalam pengambilan keputusan ekspor - impor, pada rekanan PT Twins Logistik" http://ejournal.upi.edu/ index.php/ manajerial/ article/view/1221 - diunduh tanggal 29 Juni 2018)

Suatu sistem logistik terbuat dari satu rangkaian fasilitas-fasilitas yang terhubung dengan layanan transportasi. Fasilitas-fasilitas tersebut bertempat dimana bahan baku di proses seperti di pabrik, di tempat penyimpanan, tempat pemilihan, tempat penjualan atau konsumen. Mereka termasuk pusat pembuatan dan perakitan, pergudangan dan pusat distribusi, titik permindahan, terminal transportasi, outlet riter, dan sebagainya. Sistem Informasi Logistik meliputi : pengadaan bahan baku ekspor, pencatatan pesanan barang ekspor, penyimpanan bahan baku dan barang yang sudah jadi (siap ekspor) dan pendistribusian atau pengiriman barang ekspor.

\section{Pengertian Kinerja Ekspor}

Kinerja Ekspor sebagai tingkatan dari tujuan perusahaan, baik secara ekonomi dan strategi dengan melakukan ekspor produknya kepasar luar negeri, yang dicapai melalui pelaksanaan strategi pemasaran ekspor (Cavusgil dan Zou 1994) dalam Endar Kusumawati (2004), Ada dua faktor yang mempengaruhi kinerja ekspor (Zou dan Stain, 1998 dalam Endar Kusumawati, 2004). Faktor internal yaitu : sumber daya, yang menyatakan bahwa perusahaan mempunyai keunikan, yaitu berwujud (tangible) dan tidak berwujud (intangible), sebagai sumberdaya yang dapat dikendalikan dan dapat digunakan untuk untuk menerapkan strategi mencapai efisiensi dan efektifitas. Sedangkan faktor eksternal merupakan faktor lingkungan dari luar dimana setiap perusahaan harus dapat menyesuaikan diri untuk bertahan (Zou dan Stain (1998) dalam Endar Kusumawati (2004).

Tulisan ini merupakan sumbangan pemikiran kepada PT Perkebunan Nusantara-Kab.Jember) sebagai sebuah PT (Persero) pengekspor tembakau yang cukup potensial, jika dapat memanfaatkan Sistem Informasi Logistik untuk dapat 
meningkatkan kinerja ekspornya, sebagai mana dapat dilihat dari Kerangka Pemikiran seperti dibawah ini :

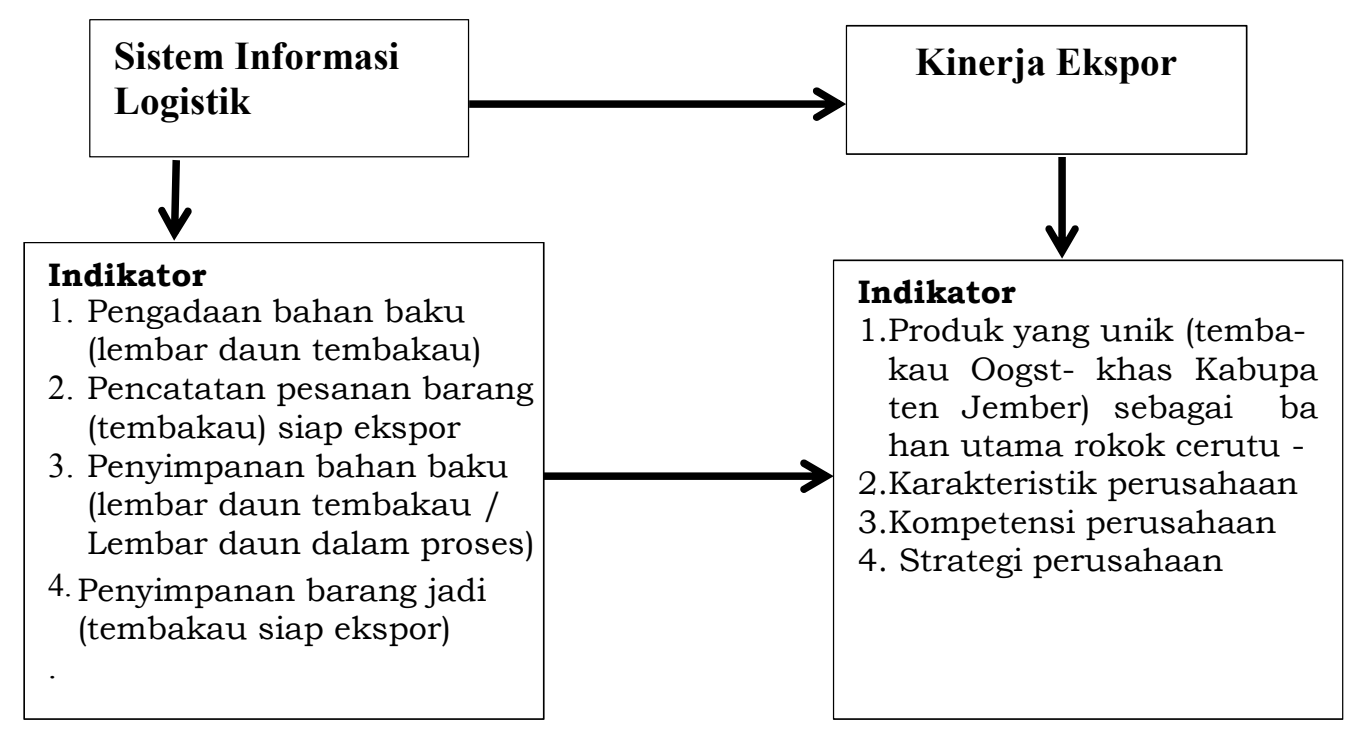

Gambar 2, Kerangka Pemikiran

\section{METODE PENULISAN}

Tulisan ini merupakan sumbangan pemikiran bagi PT Perkebunan X Kab. Jember, sebagai hasil Prada Taruna STIMART"AMNI" . Data data diperoleh dengan menggunakan teknik wawancara kepada Kepala Divisi Tembakau dan staff Operasional Lapangan. Wawancara ini dilakukan untuk mengetahui sistem tanam tembakau, proses penerimaan pesanan sampai pada proses pengiriman tembakau yang siap ekspor, pada PT Perkebunan X, Kabupaten Jember. Selain itu, dari hasil wawancara ini juga diperoleh data primair tentang belum digunakannya Sistem Informasi Logistik (pada saat taruna melaksanakan Praktek Darat). Sementara Data sekunder yang diperleh yaitu: negara tujuan ekspor tembakau PT Perkebunan X Kab. Jember. Metode Observasi juga dilakukan untuk mengetahui lokasi beberapa kebun yang terdekat.

\section{PEMBAHASAN}

\section{Sistem Informasi Logistik mensyaratkan empat indikator, yaitu :}

Sistem Informasi Logistik mensyaratkan empat indikator, yaitu : 
1. Pengadaan bahan baku (penanaman tembakau)

Pengadaan bahan baku (penanaman tembakau), sebaiknya menggunakan metode Just in Time (JIT). JIT adalah suatu sistem produksi yang dirancang untuk mendapatkan kualitas, menekan biaya, dan mencapai waktu penyerahan seefisien mungkin dengan menghapus seluruh jenis pemborosan yang terdapat dalam proses produksi, sehingga perusahaan mampu menyerahkan produknya (baik barang maupun jasa) sesuai kehen dak konsumen tepat waktu. JIT berpengaruh dalam hal mengurangi persediaan sampai pada tingkat yang sangat rendah (Don R. Hansen, Maryanne M. Mowen (2001)

JIT memecahkan masalah kinerja tepat waktu dengan cara mengu rangi waktu tunggu, dan bukannya dengan meningkatkan persediaan. Waktu tunggu dalam hal ini tidak hanya sampai pesanan diterima di perusahaan, namun sampai bahan baku (tembakau hasil panen), diolah menjadi barang jadi tembakau siap ekspor (output).

PT Perkebunan X Kab. Jember sudah menggunakan system JIT, dalam pengendalian bahan bakunya. Hal ini terbukti bahwa proyeksi penanaman tembakau cerutu yang disesuaikan dengan pesanan, sehingga tahun 2016 ini menanam sekitar 10.050 hektare untuk Tembakau Bawah Naungan (TBN) dan sebanyak 450 hektare untuk Na Oogst," Penanaman tembakau TBN yang ditanam pada Mei - Juni, sedangkan untuk Na Oogst biasanya ditanam pada bulan AgustusSeptember. Tembakau di Kebun Ajung Gayasan sudah dipesan oleh beberapa eksportir (dengan Letter of Intend ) pada tahun 2016 sebanyak 1.500 ton (Wawancara dengan Manajer Tanaman Tembakau Bawah Naungan (TBN) Kebun Ajung Gayasan PTPN X Kab. Jember, April 2016).

1.1. Pencatatan pesanan barang.

Berisi hal-hal mengenai tata-cara-pencatatan-formulir-pesananpelanggan. (http://www.ilmu-ekonomi-id.com/2017/10/html-diunduh 12 Mei 2018) :

○ Nama orang atau perusahaan pemesan

o Nama perusahaan yang dituju

o Alamat pemesan

○ Tanggal dan tempat

Majalah Ilmiah Bahari Jogja 175 | http://jurnal.amy.ac.id/index.php/MIBJ/ 
o Nama dan jenis barang (tembakau)

o Kualitas barang (kualitas tembakau)

○ Jumlah barang (ton)

- Cara pembayaran yang dilakukan

1.2. Penyimpanan bahan baku (daun tembakau)

o Penyimpanan bahan baku tidak boleh menyentuh lantai, menempel ke dinding maupun langit-langit

o Penyimpanan bahan baku harus diberi tanda dan menggunakan sis tem First In First Out (FIFO) yaitu bahan yang lebih dahulu masuk dan /atau memilki tanggal kedaluwarsa lebih awal harus digunakan terlebih dahulu.

1.3. Penyimpanan barang jadi (lembaran daun tembakau bahan cerutu) siap ekspor)

o Bahan dan produk akhir harus disimpan terpisah dalam ruangan yang bersih, sesuai dengan suhu penyimpanan, bebas hama, penerangannya cukup.

o Penyimpanan bahan jadi harus diberi tanda dan menggunakan sistem First Expired First Out (FEFO), yaitu produk akhir yang lebih dahulu diproduksi harus digunakan/diedarkan terlebih dahulu (http://informasiuntukumum.blogspot.com/2016/11/cara-penyimpa nan-bahan-yang-digunakan.html-diunduh 22 Juni 2018)

\section{Kinerja Ekspor.}

Ada empat indikator sebagai pengukur peningkatan kinerja ekspor, yaitu (Aaby, Nils-Erik dan Stanley F Slater dalam Dian Nurul Latifah http: //eprints. undip.ac.id/19693/1/Dian_Nurul_Latifah.pdf- diunduh tanggal 23 Mei 2018) :

2.1. Produk yang unik (Na Oogst) tembakau khas Jember sebagai bahan baku utama pembungkus cerutu, untuk memenuhi Pasar Eropa dan Amerika.

2.2. Karakteristik perusahaan : besaran perusahaan yang berkaitan dengan aspek kekuatan finansial dan skala ekonomis, pentingnya komitmen 
manajemen dalam ekspor, system manajemen dan rencana aktivitas ekspor dan pengalaman ekspor.

2.3. Kompetensi perusahaan : lebih penting dari Karakteristik Perusahaan, yaitu : visi internasional, tujuan ekspor yang konsisten, persepsi dan perilaku yang mendukung terhadap ekspor, kesediaan mengambil resiko dan kapabilitas melaksanakan kegiatan ekspor.

\subsection{Strategi Perusahaan dalam memasuki pasar ekspor}

PT. Perkebunan Nusantara X didirikan berdasarkan Peraturan Pemerin tah R.I No.15 Tanggal 14 Februari Tahun 1996 tentang pengalihan ben tuk Badan Usaha Milik Negara dari PT Perkebunan (Eks.PTP 19, Eks. PTP 21-22 dan Eks.PTP 27) yang dilebur menjadi PT Perkebunan Nusan tara X (Persero) dan tertuang dalam akte Notaris Harun Kamil, SH No.43 tanggal 11 Maret 1996 yang mengalami Perubahan kembali sesuai Akte Notaris Sri Eliana Tjahjoharto, SH. No. 1 tanggal 2 Desember 2011 ten tunya sudah mempunyai strategi yang unggul dalam memasuki pasar ekspor, dengan melakukan hal-hal sebagai berikut :

Sasaran pertama dan utama dari produk tembakau PTPN X adalah Burger Soehne Ag Burg (BSB) yang merupakan perusahaan dari Swiss yang membangun Bobin Industry bekerjasama dengan PTPN X. Jasa Bobbin Industry merupakan anak perusahaan dari PTPN X yang berlokasi di daerah Jelbuk Jember, dimana untuk keperluan tembakau sendiri $80 \%$ dipenuhi dari produk PTPN X. Untuk sisanya, BSB membelinya dari perusahaan lain atau bahkan impor dari negara Brazil sebagai salah satu penghasil tembakau terbaik di dunia.

Setelah kebutuhan tembakau BSB terpenuhi, maka hasil produksi yang lainya akan dipromosikan kepada pembeli tetap PTPN X yang terdiri dari pembeli produksi dan pembeli perantara. Beberapa pembeli perantara seperti Hellmering Kohne Co. (HKC) (Jerman), Anton \& Ankersmit Co. (AAC) (Jerman), Camtek Tobacco International (Amerika), dan Vetab (Amerika) merupakan pembeli perantara yang paling banyak menggunakan tembakau hasil produksi PTPN X. Sedangkan pembeli peroduksi yang banyak menggunakan tembakau hasil produksi PTPN X adalah Scandinavian Tobacco Group (STG) (Belanda, Denmark, Belgia) 
dan Royal Agio (Belanda). (Hasil Praktek Darat Taruna STIMART”AMNI" : Sofyan Winarto, pada bulan April tahun 2016).

3. Implementasi Sistim Informasi Logistik

Secara Skematik, SIL yang diusulkan untuk PTP X Kab. Jember, dapat dijelaskan pada Gambar 3, dibawah ini :

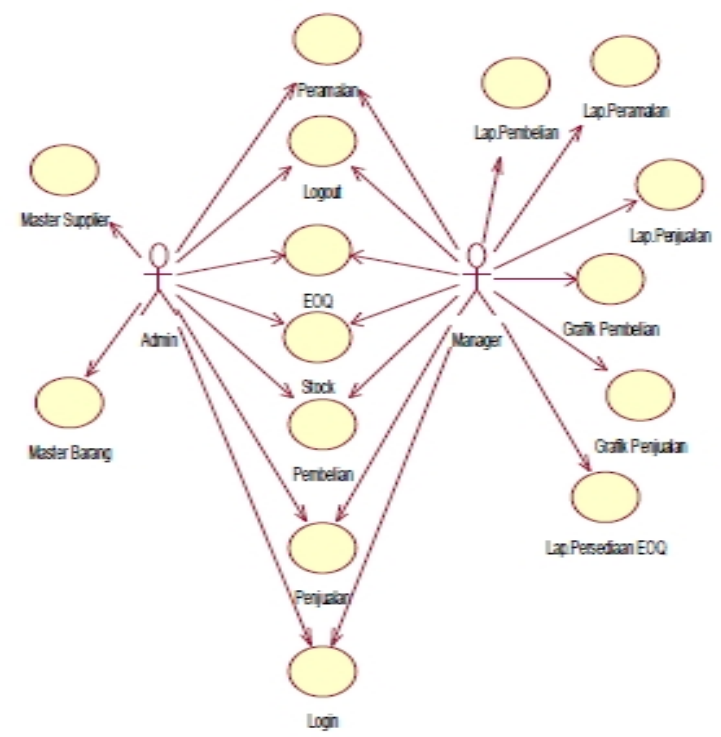

Gambar 3 : Skema SIL

Sumber : Rachmad Hidayat, 2014

Berdasarkan diagram diatas, secara umum aplikasi Sistem Informasi Logistik, mempunyai menu Login, bagi tiap-tiap user yang menampilkan beberapa menu pilihan (Rachmad Hidayat, 2014), yaitu :

\section{Admin}

Setelah sukses login, admin melakukan beberapa hal sebagai berikut :

$\begin{array}{lllll}\text { Add }, & \text { - update } & \text { delete } & \longrightarrow & \text { Data barang } \\ \text { Add, } & \text { - update } & \text { delete } & - \text { Data Supplier } \\ \text { Add, } & \text { - update } & \text { delete } & - \text { - Data Peramalan } \\ \text { Add, } & - \text { - update } & \text { delete } & - \text { Data EOQ } \\ \text { Add, } & \text { - update } & \text { delete } & - \text { Data Stok }\end{array}$

Majalah Ilmiah Bahari Jogja 178 | http://jurnal.amy.ac.id/index.php/MIBJ/ 


$\begin{array}{llll}\text { Add }, & \text { - update } & \text { delete } & \longrightarrow \\ \text { Add } & - \text { update } & \text { delete } & \longrightarrow \text { - Data Pembelian }\end{array}$

Sumber : Rachmad Hidayat, 2014

\section{Manager}

Setelah sukses login, manajer melakukan beberapa hal sebagai berikut :

\begin{tabular}{|c|c|c|c|}
\hline Add, & - update & Delete & Data barang \\
\hline Add, & - update & Delete & Data Supplier \\
\hline Add, & - update & Delete & Data Peramalan \\
\hline Add, & - update & Delete & Data EOQ \\
\hline Add, & - update & Delete & Data Stok \\
\hline Add, & - update & Delete & Data Pembelian \\
\hline Add & - update & delete & Data Penjualan \\
\hline Add & - Update & delete & Username \\
\hline Cetak & - & Grafik Penjualan & \\
\hline Cetak & - & Grafik Pembelian & \\
\hline Cetak & - & Laporan Peramalan & \\
\hline Cetak & - & Laporan EOQ & \\
\hline Cetak & - & Laporan stock & \\
\hline Cetak & & Laporan Pembelian & \\
\hline Cetak & & Laporan Penjualan & \\
\hline
\end{tabular}

Beberapa menu implementasi dari SIL ini antara lain (.....) : Menu master, yang terdiri dari : Master barang (lembaran daun tembakau) siap ekspor (2) Menu transaksi yang terdiri dari Penjualan, Persediaan (3) Menu Laporan, meliputi : Laporan Penjualan, Laporan Persediaan (4) Menu Grafik : Grafik Penjualan (5) Menu system, yaitu : yaitu Username dan About (6) Menu Login, Logout dan Exit. 
Form Login adalah login yang harus dilakukan admin dan manajer untuk memasuki halaman, seperti pada Gambar 4, dibawah ini :

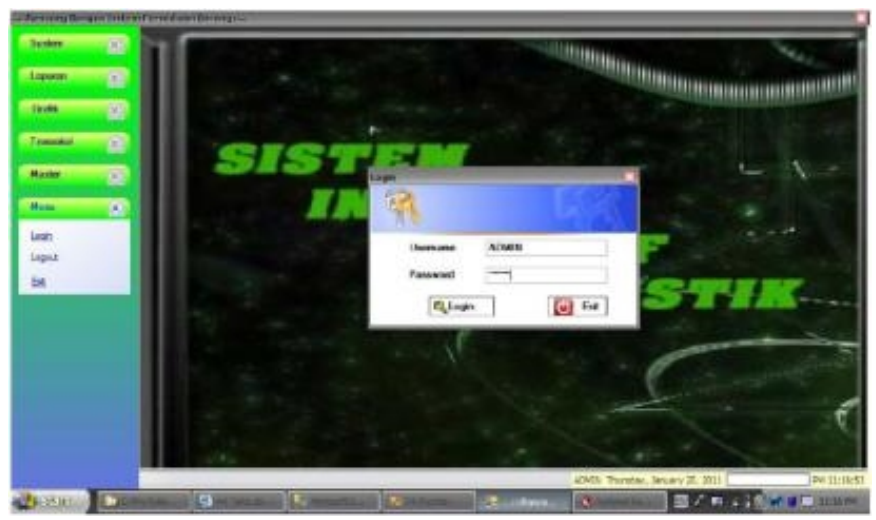

Gambar 4 Contoh form Login

Sumber : Rachmad Hidayat, 2014

\section{KESIMPULAN}

Standar dan kualitas tembakau ekspor mensyaratkan kualitas tembakau yang baik dan pasokan tembakau yang mencukupi serta kontinu. Untuk itu diperlukan pengelolaan rantai pasokan yang efektif, mulai dari lokasi dimana bahan baku (tanaman tembakau) itu ditanam, diangkut ketempat pengolahan untuk menjadikannya bahan jadi (lembaran daun tembakau) selanjutnya didistribusikan kepada pelanggan di Eropa dan Amerika, harus dilakukan secara efisen, tepat manfaat dalam waktu yang singkat.

Sistem Informasi Logistik diperlukan bagi PT Perkebunan X Kabupaten Jember, karena dapat membantu pimpinan perusahaan dalam melakukan pengawasan atas barang logistik (tanaman tembakau). Kapan tembakau harus ditanam (termasuk jenisnya : Na Oogst), luas tanam sesuai dengan jumlah pesanan atas lembaran tembakau sebagai pembungkus rokok cerutu, di negara-negara tujuan ekspor yaitu Eropa dan Amerika. 


\section{DAFTAR PUSTAKA}

Akyol, Ayse dan Gary Akehurst, 2003. An Investigation of Export Performance Variations Related to Corporate Export Market Orientation. Europe Business Review, vol 15.

Benedictus Andhika PD, Sistem Pengendalian Bahan Baku dengan Metode Just in Time (JIT) pada Ashpalt Mixing Plant PT TMPI, Jurnal Ilmiah Komputer dan Informatika (Komputa)

Cavusgil, S.Tamer, Shaoming Zou, 1994, Marketing Strategy - Performance Relationship : An Investigation of The Empirical Link in Export Market Venture. Journal of Marketing, Vol 58

Dian Nurul Latifah (2007), Analisis Faktor-Faktor yang Mempengaruhi Strategi Adaptasi Promosi Ekspor Bagi Peningkatan Kinerja Pemasaran Ekspor, http: //eprints. undip.ac.id/19693/1/Dian_Nurul_Latifah.pdf-

Rachmad Hidayat (2014), Rancang Bangun Sistem Informasi Logistik, Josi, Vol 13, 2 Oktober

Zaroni,CISP, CFM (2018), Meningkatkan ekspor Indonesia

http://sylhadisaputri19.blogspot.com/2014/06/hubungan-transportasi-denganlogistik.html

http://ejournal.upi.edu/ index.php/ manajerial/article/view/1221

(http://www.ilmu-ekonomi-id.com/2017/10/html

http://sylhadisaputri19.blogspot.com/2014/06/hubungan-transportasi-denganlogistik.html 